that these unsatisfactory conventions be continued in force and the explicit recommendation that the method of reporting the results be so modified as to eliminate evidence bearing on this matter. So I must plead guilty to supposing that Dr. Barth intended his title to mean what it said. I regret that this failure of imagination has caused him such annoyance, but can see no other reason to modify my position.

We are evidently in agreement that some general rule governing the formation of, and allocation of silica to, $p x$ and $o l$ molecules is indispensable in the treatment of under-saturated rocks, and also that the CIPW conventions provide a remarkably ingenious solution to the second but a not entirely satisfactory solution to the first of these problems. We are probably also in agreement that there is no fundamental objection to trying other appropriate solutions.

Trying alternative solutions by hand calculation is a tedious, time-consuming business. If the matter were of sufficient importance, however, it would be a relatively simple matter to prepare a machine program which would computein a single pass- norms based on as many sets of alternative $p x$-ol conventions as seemed useful, for as many analyses as were available. All we need are the sets of alternative conventions, and my note was prompted largely by a desire to stimulate presentation and discussion of these. The conventions that $\mathrm{Mg} / \mathrm{Fe}$ is the same in $o l, h y$, and $d i$, that $\mathrm{Ca}:(\mathrm{Fe}+\mathrm{Mg})=1: 1$ in $d i$, that $d i$ be desilicated only if available $\mathrm{SiO}_{2}$ is insufficient to form $l c$, and that $o l$ be silicated only after aluminates have been converted to $a b$, or, and an were proposed by CIPW in 1902. Are they still the best we can do?

GEOPHYSICAL LABORATORY,

F. Chayes.

2801, UPTON STREET,

WASHINGTON 8, D.C., U.S.A.

8th April, 1963.

\title{
VOLCANIC ROCKS OF THE ORAMUTIA SECTION, CENTRAL KENYA
}

SIR,-Dr. Rast (Geol. Mag., 100, 94-95) attributes an assumption to me which I have nowhere expressed. I have stated my opinion quite clearly in a letter to Nature $(196,365-7,1962)$, accepting that there is considerable evidence in favour of the lithostatic-load compaction and welding concept which he favours. I do not consider that the recognition of famme formed from vesiculation areas in the Kenya froth flows " must inevitably" influence the ignimbrite hypothesis. It is however a perfectly reasonable inference to draw that it may: another geologist, Grange, of the same calibre as Marshall, working on the same rocks, considered the "ignimbrites" to be lavas, and the structure to be closely related to fluidal banding in lavas. Since this is exactly what $I$ have recognized in the Kenya froth-flows, and the fiamme structure is almost identical in appearance, I do not feel that this is an unreasonable inference: but I am chiefly concerned with the Kenya field, and my primary object was to state an alternative interpretation for rocks which have been called ignimbrites by other geologists : I leave any further development of my tentative suggestion to others far more qualified than myself.

"Fiamme" is used by me and by Rast in a non-genetic sense: this has the backing of several authorities including Zavaritsky ( $\mathrm{Akad}$. Nauk. SSSR, Izv., Ser. Geol. 3, II). I have made clear, I believe, in the above paragraph, that I am not concerned with the implications of fiamme as a structure capable of only one mode of genesis: I am concerned with possible implications of the Kenya type of fiamme.

After eleven years of intermittent engagement with this problem I am of course fairly well acquainted with the vast store of literature which it has engendered. I must confess that I find it to be a jungle of terms, which are used by various authors in various ways. I find the distinction between welded tuffs and ignimbrites vaguely defined: academically speaking, that is in terms of the original writer's meaning, there is a distinction, but since some of the 
original authors who described welded-tuffs now use the term ash-flow, and use it to embrace everything from sillars to the classic ignimbrites, I cannot find a great deal of merit in retaining the distinction. Again we find that other authorities have extended the term ignimbrite: Steiner (Bull. Geol. Surv., N.Z., 68, 1960) implies a non-genetic usage, embracing both lavas and ignimbrites formed by Marshall's process (or a modification of it): Pantò (Acta Geologica, Budapest, 6, 307-331, 1962) retains the term only as a group namecover ing ignispumites (foam-lavas, froth-flows) and flood-tuffs (embracing sillars and what Rast would closely define as welded-tuffs and ignimbrites). Clearly the writer has a choice of terminology, but should clearly state which usage he follows. I myself restrict the term ignimbrite to rocks which have been formed by Marshall's process of deposition from a cloud or shower, use ash-flow to signify overland flow phenomena more closely related to the sandflow nuees ardentes than the Peleean type but involving lithostatic-load compaction effects to produce welding: while at present I am most attracted by Pantò's classification, I am not happy about extending the term ignimbrite so far from Marshall's original definition.

Pantò envisages two dissimilar processes showing convergent effects which result in suites of very similar flow-rocks, all of which he considers as ignimbrites. Rast and I both, apparently, accept the existence of foam lavas. Rast considers the compaction welding phenomenon as an established fact: I believe that relationships such as he considers certain criteria of compaction welding may be capable of another explanation: the inferences which any of us may draw from evidence are always liable to reinterpretation by others more gifted than ourselves, or others with later-gleaned evidence at hand to them. And so I retain the belief that all the very similar rocks which Pantò considers as ignimbrites, and divides into foam lavas and flood-tuffs, may yet prove to have stemmed from a primary process of foaming and frothing in a lava, and may have never suffered lithostatic load compaction effects to produce flattened fiamme structures. But this is not inevitable.

Department of Geology,

Joseph MCCALL.

UNIVERSITY OF WESTERN AUSTRALIA. 19 th April, 1963.

\section{PRE-CAMBRIAN PERTHOSITES IN NYASALAND}

SIR,-Thanks to Dr. S. W. Morel for his reply (Geol. Mag., 99, 575) to my discussion (Geol. Mag., 99, 92). Unfortunately he has not been able to join in the discussion on the main point raised, i.e. on the evolution of the perthites in the rocks described by him (Morel, 1961). Dr. Morel's reply does not add any new data (on the perthites) which were lacking in his original paper. The feldspar, which is stated to have crystallized " after the directional forces had ceased" (Morel, 1961, 241) is again claimed to have suffered metamorphism and consequent exsolution (Morel, 1962, 575). The idea that the original feldspar was anorthoclase, should find support with more data. It would be interesting to know the details of the perthites formed by deformation, and which apparently resemble the perthites of magmatic origin, as noted in my discussion. Dr. Morel (1961) did not make any firm statement regarding para-kinematic origin of the rocks, the idea expressed now in words of other authors (Morel, 1962, 575). In general, Dr. Morel's observations need clarification regarding the nature, composition, and origin of the perthites and their time relation with deformation. It is interesting to note further that he is now inclined towards a metasomatic origin of the perthitic rocks.

\section{REFERENCE}

Morel, S. W., 1961. Pre-cambrian perthosites in Nyasaland. Geol. Mag., 98, 235-244.

DEPARTMENT OF GEOLOGY,

MiHIR K. Bose.

Presidency College, Calcutta. 19th March, 1963. 